\begin{tabular}{|c|c|c|}
\hline restomive & \begin{tabular}{|l} 
Al Fitrah \\
Journal Of Early Childhood Islamic Education \\
ISSN : 2599-2287 \\
Vol.1 No.2 Januari 2018
\end{tabular} & $\begin{array}{r}\text { Manajemen Pengelolaan Labschool Program } \\
\text { Studi PIAUD Fakultas Tarbiyah dan Tadris } \\
\text { IAIN Bengkulu } \\
\text { Yenti Sumarni }\end{array}$ \\
\hline
\end{tabular}

\title{
MANAJEMEN PENGELOLAAN LABSCHOOL PROGRAM STUDI PIAUD FAKULTAS TARBIYAH DAN TADRIS IAIN BENGKULU
}

\begin{abstract}
Abstrak
Penelitian ini berawal dari ketertarikan penulis terhadap keistimewaan labschool PIAUD IAIN Bengkulu. Keistimewaan tersebut antara lain guru yang membimbing masih belum memenuhi standar kualifikasi akademik seperti lulusan Diploma IV atau S1, serta orang tua dan masyarakat sekitar yang selalu mendukung keberadaan labschool PIAUD IAIN Bengkulu. Penelitian ini bertujuan untuk menganalisis Manajemen Pengelolaan Pendidikan Anak Usia Dini yang meliputi Planning, Organizing, Actuating, Controling. Penelitian ini merupakan penelitian kualitatif dengan mengambil latar di labschool PIAUD IAIN Bengkulu. Teknik pengumpulan data yang dilakukan dengan cara observasi, wawancara dan dokumentasi. Hasil penelitian menunjukan: (1) pola pengelolaan pendidikan anak usia dini labschool PIAUD IAIN Bengkulu menggunakan metode POAC (Planning, Organizing, Actuating, Controling). (2) faktor pendukung dalam pengelolaan pendidikan anak usia dini adalah: adanya semangat belajar siswa, adanya kerjasama antara sesama pendidik, terdapat peran dari masyarakat, adanya sikap sering terbuka antara pendidik dengan orang tua siswa, adanya kerjasama antara guru dengan orang tua siswa, terdapat kerjasama dari pemerintah/kampus. (3) Hasil manajemen pengelolaan labschool PIAUD IAIN Bengkulu adalah: peningkatan jumlah siswa yang cukup meningkat pada setiap bulannya.
\end{abstract}

Yenti Sumarni

iyent_mr@ymail.

com

Kata Kunci : Manajemen Pengelolaan, PIAUD

\begin{tabular}{llll}
\hline Pendahuluan & & pendidikan baik pendidikan & formal, \\
Pendidikan merupakan suatu & informal maupun non formal. Pada \\
kebutuhan bagi setiap makhluk hidup. & dasarnya pendidikan merupakan proses \\
Makluk hidup akan memperoleh & untuk membantu manusia & dalam \\
pendidikan baik dari lingkungan maupun & pengembangan dirinya untuk mampu \\
dari lingkungan keluargamya. Begitupun & menghadapi setiap perubahan yang terjadi \\
individu manusia membutuhkan & dalam kehidupan.
\end{tabular}




\begin{tabular}{|l|l|r|}
\hline A1 Fitrah & Manajemen Pengelolaan Labschool Program \\
Journal Of Early Childhood Islamic Education & Studi PIAUD Fakultas Tarbiyah dan Tadris \\
ISSIN Bengkulu \\
ISS : 2599-2287 & Yenti Sumarni \\
\hline
\end{tabular}

Tujuan utama dunia pendidikan adalah pemerataan pendidikan baik dari wilayah perkotaan maupun pedesaan. Hal ini sesuai dalam pembukaan Undangundang Dasar 1945 yang berbunyi:

"Kemudian dari pada itu untuk membentuk suatu pemerintahan Negara Indonesia yang melindungi segenap bangsa Indonesia dan seluruh tumpah darah Indonesia dan untuk memajukan kesejahteraan umum, mencerdaskan kehidupan bangsa, dan ikut melaksanakan ketertiban dunia yang berdasarkan kemerdekaan, perdamaian abadi dan keadilan sosial.”

Untuk mewujudkan hal tersebut, pemerintah telah menyediakan dana khusus bagi pendidikan yaitu 20\% dari dana APBN. Terbukti dalam Undangundang 1945 pasal 31 ayat 4 yang berbunyi:

"Negara memprioritaskan anggaran pendidikan sekurang-kurangnya dua puluh persen dari anggaran pendapatan dan belanja negara serta dari anggaran pendapatan dan belanja daerah untuk memenuhi kebutuhan penyelenggaraan pendidikan Nasional.",2

Hal ini juga untuk mendukung persaingan global, pendidikan diharapkan dapat dimanfaatkan secara merata. Pendidikan memberikan kesempatan seluas-luasnya kepada anak didik untuk tumbuh dan berkembang sesuai dengan

1 Republik Indonesia, Undangundang Dasar 1945, pembukaan.

2 Ibid,. potensi, bakat, minat dan kesanggupannya. penyelenggaraan pendidikan yang membebaskan anak dari tindak kekerasan. Pelaksanaan pendidikan yang memperlakukan anak dengan ramah, pendidikan yang memanusiakan anak serta pendidikan yang memenuhi hak-hak anak. Hal ini akan terwujud jika pendidikan yang demikian dilakukan sejak anak usia dini.

Pendidikan anak usia dini (PAUD) merupakan fondasi bagi perkembangan kualitas sumber daya manusia selanjutnya. Karena itu peningkatan penyelenggaraan PAUD sangat memegang peranan yang penting untuk kemajuan pendidikan di masa mendatang. Arti penting mendidik anak sejak usia dini dilandasai dengan kesadaran bahwa masa kanak-kanak adalah masa keemasan (the Golden Age), karena dalam rentang usia dari 0 sampai 5 tahun, perkembangan fisik, motorik dan berbahasa atau linguistik seorang anak akan tumbuh dengan pesat. Selain itu anak pada usia 2 sampai 6 tahun dipenuhi dengan senang bermain. Konsep bermain sambil belajar serta belajar sambil bermain pada PAUD merupakan pondasi yang mengarahkan anak pada pengembangan kemampuan yang lebih beragam, sehingga di kemudian hari anak bisa berdiri kokoh dan menjadi sosok manusia yang berkualitas. 


\begin{tabular}{|l|l|r|}
\hline Al Fitrah & Manajemen Pengelolaan Labschool Program \\
Journal Of Early Childhood Islamic Education & Studi PIAUD Fakultas Tarbiyah dan Tadris \\
ISIN Bengkulu \\
ISSN : 2599-2287 & Yenti Sumarni \\
Vol.1 No.2 Januari 2018 & \\
\hline
\end{tabular}

Pendidikan anak usia dini sangatlah penting karena kapabilitas kecerdasan orang dewasa terjadi ketika anak berusia 4 tahun dan terjadi perkembangan yang sangat pesat tentang jaringan otak ketika anak berumur 8 tahun dan akan mencapai puncak kecerdasan pada anak berusia 18 tahun. Masa perkembangan kecerdasan anak tersebut sering disebut dengan masa emas dan masa tersebut hanya datang sekali, sehingga apabila terlewatkan berarti habislah peluangnya. Pendidikan anak usia dini akan memberikan anak kesiapan menghadapi masa-masa kedepan yaitu menghadapi masa sekolah, misalnya saja memberikan kemampuan dalam hal membaca, menulis, dan mengenal warna karena di usia inilah anak usia dini dibentuk kesiapan dirinya untuk menghadapi masa sekolah dan masa depannya sebagai investasi terbaik untuk persiapan pendidikan mereka di usia dini. ${ }^{3}$

Untuk itu pengembangan program PAUD harus digalakkan di berbagai tempat di wilayah Indonesia. Pendidikan anak memang harus dimulai sejak dini, agar anak bisa mengembangkan potensinya secara optimal. Anak-anak yang mengikuti

${ }^{3}$ Dyah Fifin Fatimah dan Nur Rohma. Pola Pengelolaan Pendidikan Anak Usia Dini di Paud Ceria Gondangsari Jawa Tengah. Jurnal Manageria: Jurnal Manajemen Pendidikan Islam Volume 1, Nomor 2, November 2016. Hal.249
PAUD menjadi lebih mandiri, disiplin, dan mudah diarahkan untuk menyerap ilmu pengetahuan secara optimal. Hal ini harus dimengerti oleh setiap orang tua, dengan memberikan stimulasi yang tepat agar kemampuan anak tersebut teraktualisasi dan berkembang dengan optimal.

Selain pentingnya pendidikan dini yang di dapatkan oleh anak, hal yang tidak kalah penting adalah cara mendidik guru dalam proses pembelajaran. Proses dalam memberikan materi untuk pendidikan anak usia dini (PAUD) sangat berbeda, ada beberapa syarat dalam mendidik anak usia dini. Sesuai peraturan Menteri Pendidikan Nasional Nomor 58 Tahun 2009 tentang Standar Pendidikan Anak Usia Dini Indonesia bab III tentang Standar Pendidik dan Tenaga Kependidikan dinyatakan bahwa pendidik anak usia dini adalah profesional yang bertugas merencanakan, melaksanakan proses pembelajaran, dan menilai hasil pembelajaran, serta melakukan pembimbingan, pengasuhan dan perlindungan anak didik. ${ }^{4}$

Menjadi guru pada PAUD tidak sembarangan, melainkan ada kualifikasi khusus agar nantinya hasil yang diperoleh dalam proses pembelajaran dapat maksimal dan menciptakan lulusan yang

4 Mukhtar Latif, dkk, Orientasi Baru Pendidikan Anak Usia Dini Teori dan Aplikasi, (Jakarta: Kencana Prenademedia, 2014), hlm. 246. 


\begin{tabular}{|l|l|r|}
\hline A1 Fitrah & Manajemen Pengelolaan Labschool Program \\
Journal Of Early Childhood Islamic Education & Studi PIAUD Fakultas Tarbiyah dan Tadris \\
ISSIN Bengkulu \\
ISS : 2599-2287 & Yenti Sumarni \\
\hline
\end{tabular}

baik seperti visi dan misi PAUD. Dijelaskan dalan UU RI No. 14 Tahun 2005 tentang Guru dan Dosen, bab IV bagian kesatu kualifikasi, kompetensi dan sertifikasi pasal 8 yaitu guru wajib memiliki kualifikasi akademik, kompetensi, sertifikasi pendidikan, sehat jasmani dan rohani, serta memiliki kemampuan untuk mewujudkan tujuan pendidikan nasional. Kemudian pada pasal 9 kualifikasi akademik sebagaimana yang dimaksud pada pasal 8 diperoleh melalui pendidikan tinggi program sarjana atau diploma empat (D4). ${ }^{5}$

Permendiknas No.16 Tahun 2007 juga dijelaskan bahwa Guru pada PAUD/ TK/ RA harus memiliki kualifikasi akademik pendidikan minimum diploma empat (D4) atau sarjana dalam bidang pendidikan anak usia dini atau psikologi yang diperoleh dari program studi yang terakreditasi. $^{6}$

Proses pendidikan dan pembelajaran pada anak usia dini hendaknya dilakukan dengan tujuan memberikan konsep yang bermakna bagi anak melalui pengalaman nyata. Hanya pengalaman nyatalah yang memu ngkinkan anak menunjukkan aktivitas dan

5 Republik Indonesia, Undangundang RI No. 14 Tahun 2005 tentang Guru dan Dosen, Bab IV, Pasal 8 \& 9

6 Republik Indonesia, Undangundang RI No.16 Tahun 2007. rasa ingin tahu (curiousity) secara optimal dan menempatkan posisi pendidik sebagai pendamping, pembimbing serta fasilitator bagi anak

Menyikapi beberapa permasalahan tersebut, maka Program Studi PIAUD Fakultas Tarbiyah dan Tadris IAIN Bengkulu mendirikan Labschool PIAUD sebagai wadah pembelajaran persiapan baik bagi mahasiswa maupun alumni yang baru lulus. Sehingga para alumni dan mahasiswa dapat langsung praktek pengajaran pada labschool tersebut, sehingga diharapkan mampu mencetak para pendidik yang profesional. Labschool PIAUD ini telah menerima peserta didik dari umur 0-6 tahun. Walaupun hanya sebagai wadah pembelajaran, namun pelaksanaannya tetap memperhatikan keutamaan dalam pelayanan seperti halnya PIAUD umumnya.

Keberadaan Labschool PIAUD IAIN Bengkulu ini termasuk dalam rangka untuk mengembangkan potensi anak pra sekolah dasar untuk sedini mungkin memiliki kecakapan dalam hal keilmuan. Tentunya hal ini dimungkinkan dengan adanya suatu tatanan yang baik dari pengelolaan sekolah dalam hal ini bersifat manajerial. Peneliti dalam hal ini akan menautkan antara fungsi administrasi dan manajemen yang diberlakukan pada lembaga ini dengan 


\begin{tabular}{|l|l|r|}
\hline \multirow{2}{*}{\begin{tabular}{|l|r|} 
Al Fitrah \\
Journal Of Early Childhood Islamic Education \\
ISSN : 2599-2287
\end{tabular}} & $\begin{array}{r}\text { Manajemen Pengelolaan Labschool Program } \\
\text { Studi PIAUD Fakultas Tarbiyah dan Tadris } \\
\text { IAIN Bengkulu } \\
\text { Vol.1 No.2 Januari 2018 }\end{array}$ \\
\hline
\end{tabular}

keberhasilan pendidikan PAUD yang berfungsi untuk mempersiapkan anak-anak usia dini untuk dapat memahami pengetahuan sesuai dengan kebutuhannya.

Dengan kata lain untuk menunjang semua hal tersebut, pengelolaan PAUD membutuhkan suatu perencanaan yang partisipatif, yakni dengan melibatkan semua pihak yang terlibat dalam kegiatan mulai dari perencanaan, pelaksanaan, evaluasi, sampai pemanfaatan program yang direncanakan. Hal ini dilatari oleh asumsi bahwa orang yang merasa terlibat dalam proses sejak perencanaan sampai tahap akhir merasa ikut memiliki dan ikut bertanggungjawab (sense of responsibility and sense of belongingness) terhadap keberhasilan pendidikan yang dilakukan. ${ }^{7}$

Dari latar belakang diatas, penulis tertarik untuk meneliti Labschool PIAUD Fakultas Tarbiyah dan Tadris IAIN Bengkulu dengan judul tulisan Manajemen Pengelolaan Labschool Program Studi PIAUD Fakultas Tarbiyah dan Tadris IAIN Bengkulu. Penelitian ini bertujuan untuk menganalisis manajemen pengelolaan Pendidikan Anak Usia Dini yang meliputi Planning, Organizing, Actuating, Controling serta ingin melihat seberapa besar perubahan pola pikir masyarakat

7 PADU, 2004. Buletin PADU. Jurnal Ilmiah Anak Usia Dini, Jakarta: Departemen Pendidikan Nasional, 2004. Hal.39-44 mengenai pendidikan anak usia dini. Penelitian ini merupakan penelitian kualitatif dengan mengambil latar di Labschool Program Studi PIAUD Fakultas Tarbiyah dan Tadris IAIN Bengkulu. Yang dilakukan pada Bulan Januari-Maret 2018. Teknik pengumpulan data yang dilakukan dengan cara observasi, wawancara dan dokumentasi.

\section{Pengertian Manajemen Pengelolaan \\ Pendidikan}

Perkembangan dinamis aplikasi manajemen berangkat dari keragaman definisi tentang manajemen. Semula, manajemen yang berasal dari bahasa Inggris: management dengan kata kerja to manage, diartikan secara umum sebagai mengurusi atau kemampuan menjalankan dan mengontrol suatu urusan atau "act of running and controlling a business” . 8

Sedangkan menurut Haroid dan cyrilo Donnel mengemukakan managament is getting things done throug people in bringing about tjis coordinating of group activity the manager, as a manager plans, organizes, staffs, direct, and control the acktivities other people. Artinya manajemen adalah usaha mencapai tujuan tertentu melalui kegiatan orang lain. Dengan demikian manajemen mengadakan kordinasi atas sejumlah aktivitas orang lain

8 Oxford, Learner's Pocket Dictionary. Newyork, Oxford University Press.2005. 


\section{Al Fitrah Journal Of Early Childhood Islamic Education ISSN : 2599-2287 \\ Vol.1 No.2 Januari 2018}

yang meliputi

perencanaan, pengorganisasian, penempatan, pengarahan, dan pengendalian. ${ }^{9}$

Manajemen kemudian diartikan sebagai suatu rentetan langkah yang terpadu untuk mengembangkan suatu organisasi sebagai suatu system yang bersifat sosio-ekonomi-teknis; dimana system adalah suatu kesatuan dinamis yang terdiri dari bagian-bagian yang berhubungan secara organik; dinamis berarti bergerak, berkembang ke arah suatu tujuan; sosio (social) berarti yang bergerak di dalam dan yang menggerakkan sistem itu adalah manusia; ekonomi berarti kegiatan dalam sistem bertujuan untuk memenuhi kebutuhan manusia; dan teknis berarti dalam kegiatan dipakai harta, alatalat dan cara-cara tertentu. ${ }^{10}$

Dalam pengertian

Manajemen

Pendidikan ini, manajemen bukan hanya pengaturan yang terkait dengan pekerjaan tulis-menulis, tetapi pengaturan dalam arti luas Selain itu, Manajemen berasal dari kata to manage yang berarti mengelola. Pengelolaan dilakukan melalui proses dan dikelola berdasarkan urutan dan fungsifungsi manajemen itu sendiri. Manajemen adalah melakukan pengelolaan sumber daya yang dimiliki oleh sekolah atau

9 Malayu, Manajemen, (Jakarta: Bumi Aksara, 2006), hlm. 1-3.

10 Kadarman, A. M. et. a. Pengantar Ilmu Manajemen. Jakart: gramedia. 1996
Manajemen Pengelolaan Labschool Program Studi PIAUD Fakultas Tarbiyah dan Tadris IAIN Bengkulu Yenti Sumarni organisasi yang diantaranya adalah manusia, uang, metode, material, mesin dan pemasaran yang dilakukan dengan sistematis dalam suatu proses.

Manajemen pendidikan adalah suatu proses dari perencanaan pengorganisasian, pengarahan, pengawasan, dan penilaian usaha-usaha pendidikan supaya dapat mencapai tujuan pendidikan yang telah di tetapkan sebelumnya.Atau definisi manajemen pendidikan yang lainnya yaitu merupakan suatu bentuk kerjasama antar pihak-pihak pendidikan demi pencapai target pendidikan yang telah di tetapkan sebelumnya. Yang menjadi tujuan umum dalam manajemen pendidikan adalah melaksanakan pembentukan kepribadian pelajar yang berdasarkan dengan tujuan dari pendidikan nasional dan tingkat perkembangan maupun perbaikan untuk usia pendidikan.

Jika manajemen pendidikan sudah tertata dengan baik dan membumi, niscaya tidak akan lagi terdengar tentang pelayanan sekolah yang buruk, minimnya profesionalisme tenaga pengajar, saranaprasarana tidak memadai, pungutan liar, hingga kekerasan dalam pendidikan. Manajemen dalam sebuah organisasi pada dasarnya dimaksudkan sebagai suatu proses (aktivitas) penentuan dan pencapaian tujuan organisasi melalui 


\begin{tabular}{|c|c|c|}
\hline & $\begin{array}{l}\text { Al Fitrah } \\
\text { Journal Of Early Childhood Islamic Education } \\
\text { ISSN : 2599-2287 } \\
\text { Vol.1 No.2 Januari } 2018\end{array}$ & $\begin{array}{r}\text { Manajemen Pengelolaan Labschool Program } \\
\text { Studi PIAUD Fakultas Tarbiyah dan Tadris } \\
\text { IAIN Bengkulu } \\
\text { Yenti Sumarni }\end{array}$ \\
\hline
\end{tabular}

pelaksanaan empat fungsi dasar: planning, organizing, actuating, dan controlling dalam penggunaan sumberdaya organisasi.

\section{Perencanaan (Planing)}

Satu-satunya hal yang pasti di masa depan dari organisasi apapun termasuk lembaga pendidikan adalah perubahan, dan perencanaan penting untuk menjembatani masa kini dan masa depan yang meningkatkan kemungkinan untuk mencapai hasil yang diinginkan. Perencanaan merupakan proses menentukan apa yang seharusnya dicapai dan bagaimana mewujudkannya dalam kenyataan. ${ }^{11}$ Perencanaan amat penting untuk implementasi strategi dan evaluasi strategi yang berhasil, terutama karena aktivitas pengorganisasian, pemotivasian, penunjukkan staff, dan pengendalian tergantung pada perencanaan yang baik. ${ }^{12}$

$$
\text { Rusdiana mengutip pendapat }
$$
Mulyasa, manajemen pendidikan sebagai segala yang berkenaan dengan pengelolaan proses pendidikan untuk mencapai tujuan yang telah di tetapkan, baik tujuan jangka pendek, menengah, maupun jangka panjang. ${ }^{13}$

11 Mondy, R.W.and Premeaux, S. Management: Concepts, Practices and Skills. New Jersey: Prentice Hall Inc Englewood Cliffs. 1995

12 David, R. F. Konsep Manajemen Strategis. PT Indeks (VII).2004

13 Rusdiana, Pengelolaan Pendidikan, (Bandung: Pustaka Setia, 2015), hlm. 13.
Berbeda dengan Philip H. Combs mengemukakan lima ciri perencanaan pendidikan, yaitu: (1) berpandangan jangka panjang, (2) terperinci, (3) diintegrasikan dengan rencana ekonomi yang lebih luas dan perkembangan masyarakat, merupakan bagian integral pengelolaan pendidikan, dan (5) memperhitungkan bagian kualitatif, karena perkembangan pendidikan bukan perluasan secara kuantitatif saja. ${ }^{14}$

Pengorganisasian (Organizing)

Tujuan pengorganisasian adalah mencapai usaha terkoordinasi dengan menerapkan tugas dan hubungan wewenang. Pengorganisasian sebagai suatu proses penentuan, pengelompokkan dan pengaturan bermacam-macam aktivitas yang diperlukan untuk mencapai tujuan, menempatkan orang-orang pada setiap aktivitas ini, menyediakan alat-alat yang diperlukan, menetapkan wewenang yang secara relative didelegasikan kepada setiap individu yang akan melakukan aktivitasaktivitas tersebut. ${ }^{15}$

Dengan demikian, pengorganisasian pendidikan merupakan pengaturan seluruh sumber daya pendidikan dalam rangka mencapai tujuan pendidikan.20 Unsurunsur dasar yang membentuk sebuah

14 Ibid.,

15 Hasibuan, S. P. M. Manajemen Sumber Daya Manusia (II). Jakart: PT Toko Gunung Agung. 1995 


\begin{tabular}{|l|l|r|}
\hline A1 Fitrah & Manajemen Pengelolaan Labschool Program \\
Journal Of Early Childhood Islamic Education & Studi PIAUD Fakultas Tarbiyah dan Tadris \\
ISSIN Bengkulu \\
ISS : 2599-2287 & Yenti Sumarni \\
\hline
\end{tabular}

organisasi adalah sebagi berikut: (1) adanya tujuan bersama. Organisasi mensyaratkan sesuatu yang akan diinginkan, biasanya terumuskan dalam visi, misi, target, dan tujuan. Tujuan inilah yang menyatukan berbagai unsur dalam organisasi, (2) adanya kerjasama dua orang atau lebih. Oganisasi terbentuk karena adanya kerjasama untuk mencapai tujuan yang diinginkan bersama, (3) adanya pembagian tugas. Untuk efektifitas, efisiensi, dan produktivitas organisasi dibutuhkan pembagian tugas, dan (4) adanya kehendak untuk bekerjasama. Anggota organisasi mempunyai kemauan atau kehendak untuk bekerjasama untuk mencapai tujuan bersama. ${ }^{16}$

\section{Pelaksanaan (Actuating)}

Menurut Kadarman, kepemimpinan dapat diartikan sebagai seni atau proses untuk mempengaruhi dan mengarahkan orang lain agar mereka mau berusaha untuk mencapai tujuan yang hendak dicapai oleh kelompok. Kepemimpinan juga dapat didefinisikan sebagai suatu kemampuan, proses 6 atau fungsi yang digunakan untuk mempengaruhi dan mengarahkan orang lain untuk berbuat

16 Didin Kurniadin \& Imam Machali, Manajemen Pendidikan Konsep \& Prinsip Pengelolaan Pendidikan, (Yogyakarta: ArRuzz Media, 2012), hlm. 241. sesuatu dalam rangka mencapai tujuan tertentu. ${ }^{17}$

$$
\text { Pelaksanaan atau actuating }
$$
merupakan fungsi manajemen yang terpenting dan paling dominan dalam proses manajemen. Dalam pelaksanaanya, pelaksanaan tidak dapat dilepaskan dari fungsi manajer sebagai pemimpin. Oleh sebab itu, diperlukan kepemimpinan.

\section{Pengawasan (Controling)}

Pengawasan sebagai suatu upaya sistematis untuk menetapkan standar prestasi kerja dengan tujuan perencanaan untuk mendesain sistem umpan balik informasi; untuk membandingkan prestasi sesungguhnya dengan standar yang telah ditetapkan itu; menentukan apakah ada penyimpangan dan mengukur signifikansi penyimpangan tersebut; dan mengambil tindakan perbaikan yang diperlukan untuk menjamin bahwa semua sumberdaya perusahaan telah digunakan dengan cara yang paling efekif dan efisien guna tercapainya tujuan perusahaan.

Nanang Fattah berpendapat yang di kutip oleh Rusdiana bahwa proses dasarnya terdiri atas tiga tahap, yaitu menetapkan standar pelaksanaan, pengukuran pelaksanaan dibandingkan dengan standar, dan menentukan Ilmu...

17 Kadarman, A. M. et. a. Pengantar 


\begin{tabular}{|l|l|r|}
\hline Al Fitrah & Manajemen Pengelolaan Labschool Program \\
Journal Of Early Childhood Islamic Education & Studi PIAUD Fakultas Tarbiyah dan Tadris \\
ISSN $:$ 2599-2287 & YAngkulu \\
ISS & Yenti Sumarni \\
\hline
\end{tabular}

kesenjangan antara pelaksanaan dan standar. $^{18}$

\section{Pendidikan Anak Usia Dini}

Sebelum dibicarakan tentang pendidikan terlebih dahulu akan dibahas tentang anak usia dini. Adapun yang dimaksud dengan anak usia dini adalah sekelompok manusia yang berusia 0-6 tahun. $^{19}$

Adapun berdasarkan para pakar pendidikan anak, anak usia dini ialah sekelompok manusia yang berusia 0-8 tahun. ${ }^{20}$ Anak usia dini adalah kelompok anak yang berada dalam proses pertumbuhan dan perkembangan yang bersifat unik, dalam arti memiliki pola pertumbuhan dan perkembangan (koordinasi motorik halus dan kasar), intelegensi (daya pikir, daya cipta, kecerdasan emosi, dan kecerdasan spiritual), sosial emosional (sikap dan perilaku serta agama), bahasa dan komunikasi yang khusus sesuai dengan tingkat pertumbuhan dan perkembangan

18 Rusdiana, "Pengelolaan..., hlm.16.

19 Tn. Himpunan PerundangUndangan Republik Indonesia tentang SISDIKNAS dan Penyelenggaraan Pendidikan. Bandung: Citra Umbara. 2010. Hlm. 8.

20 Depdiknas. Kurikulum Hasil Belajar Pendidikan Anak Usia Dini. Jakarta: Depdiknas. 2002. Hal.3-4 anak. Berdasarkan keunikan dalam pertumbuhan dan perkembangannya, anak usia dini terbagi dalam tiga tahapan, yaitu (a) masa bayi lahir sampai 12 bulan, (b) masa toddler (batita) usia 1-3 tahun, (c) masa prasekolah usia 3-6 tahun, (d) masa kelas awal SD 6-8 tahun. Pertumbuhan dan perkembangan anak usia dini perlu diarahkan pada peletakan dasar-dasar yang tepat bagi pertumbuhan dan perkembangan manusia seutuhnya, yaitu pertumbuhan dan perkembangan fisik, daya pikir, daya cipta, sosial emosional, bahasa dan komunikasi yang seimbang sebagai dasar pembentukan pribadi yang utuh. $^{21}$

Pendidikan Anak Usia Dini (PAUD) adalah jenjang pendidikan sebelum jenjang pendidikan dasar yang merupakan suatu upaya pembinaan yang ditujukan bagi anak sejak lahir sampai dengan anak usia enam tahun yang dilakukan melalui pemberian rangsangan pendidikan untuk membantu pertumbuhan dan perkembangan jasmani dan rohani agar anak memiliki kesiapan dalam memasuki pendidikan lebih lanjut, yang diselenggarakan pada jalur formal, non formal, dan informal. ${ }^{22}$

21 Bambang Hartoyo. Konsep Dasar Pendidikan Anak Usia Dini. Materi Tutor dan Pengelola Pendidikan Anak Usia Dini, di BPPLSP Regional III Jawa Tengah. 2004. Hlm.3.

22 Fari Ulfah, Manajemen PAUD Pengembangan Jejaring Kemitraan 


\begin{tabular}{|l|l|r|}
\hline A1 Fitrah & Manajemen Pengelolaan Labschool Program \\
Journal Of Early Childhood Islamic Education & Studi PIAUD Fakultas Tarbiyah dan Tadris \\
ISSIN Bengkulu \\
ISS : 2599-2287 & Yenti Sumarni \\
\hline
\end{tabular}

Dengan demikian, PAUD dapat di deskripsikan sebagai berikut :Pertama, Pendidikan Anak Usia Dini (PAUD) adalah pemberian upaya untuk menstimulasi, membimbing, mengasuh, dan pemberian kegiatan pembelajaran yang akan menghasilkan kemampuan dan keterampilan pada anak. Kedua, Pendidikan Anak Usia Dini (PAUD) merupakan salah satu bentuk penyelenggaraan yang menitikberatkan pada peletakan dasar kearah pertumbuhan dan perkembangan fisik (koordinasi motorik halus dan kasar), kecerdasan (daya pikir, daya cipta, kecerdasan emosi, dan kecerdasan spiritual), sosio-emosional (sikap perilaku serta agama), bahasa dan komunikasi.Ketiga, sesuai dengan keunikan dan pertumbuhan Pendidikanan Usia Dini (PAUD) disesuaikan dengan tahap-tahap perkembangan yang dilalui oleh anak usia dini. ${ }^{23}$

\section{Manajemen Pengelolaan Labschool}

\section{Program Studi PIAUD IAIN Bengkulu}

\section{Perencanaan (Planing)}

Perencanaan pendidikan pada PAUD AlFath Sabang menurut penulis sudah baik, karena dalam proses pembuatannya

Belajar, (Yogyakarta: Pustaka Pelajar, 2015), hlm. 22

${ }_{23}$ Mansur. Pendidikan Anak Usia Dini Dalam Islam. Yogyakarta: Pustaka Pelajar. 2009. Hlm.88-89. turut melibatkan berbagai pihak, terutama guru. Kecuali itu, proses penyusunan kurikulum dan program pembelajaran yang dilakukan di PAUD Al-Fath juga telah melalui tahapan-tahapan perencanaan, pengorganisasian, pelaksanaan dan pengawasan. Hal ini sesuai dengan arahan Depdiknas $^{24}$ yang mengutarakan bahwa pelaksanaan kurikulum di sekolah melalui empat tahap, yaitu: 1. Perencanaan. 2. Pengorganisasian dan koordinasi. 3. Pelaksanaan. 4. Pengendalian/pengawasan.

Pada perencanaan ini masing-masing guru dibagi tugas oleh kepala sekolah untuk menangani siswa dengan dasar pembagian tugas satu guru satu siswa, sehingga guru dapat fokus dalam pengajaran setiap siswanya.

Demikian juga dengan pembagian tugas kepada guru yang dilakukan oleh Kepala Sekolah, dengan musyawarah dan kebersamaan. Pihak Kepala Sekolah telah berupaya maksimal menerapkan kebersamaan dan koordinasi dalam setiap aktifitas, mulai dari perencanaan sampai pengawasan terkait dengan kurikulum dan program belajar yang akan dilaksanakan. Hal tersebut telah menunjukkan danya kepercayaan yang penuh terhadap proses pendidikan yang dilaksanakan pendidik

24 Depdiknas. Menuju Pendidikan yang Bermutu dan Merata. (Jakarta: Balai Pustaka 2007) hal.68 


\begin{tabular}{|c|c|c|}
\hline & $\begin{array}{l}\text { Al Fitrah } \\
\text { Journal Of Early Childhood Islamic Education } \\
\text { ISSN : } 2599-2287 \\
\text { Vol.1 No.2 Januari } 2018\end{array}$ & $\begin{array}{r}\text { Manajemen Pengelolaan Labschool Program } \\
\text { Studi PIAUD Fakultas Tarbiyah dan Tadris } \\
\text { IAIN Bengkulu } \\
\text { Yenti Sumarni }\end{array}$ \\
\hline
\end{tabular}

dalam kegiatan pendidikan di labschool PIAUD IAIN Bengkulu. Sejalan dengan hal tersebut, Pidarta $^{25}$ mengemukakan bahwa pekerjaan dalam tiap unit kerja dibagi-bagikan kepada personalia dalam tiap unit itu sesuai dengan komptensinya masing-masing.

Pendidikan non akademik seperti pendidikan agama sangat penting karena akan menjadi pondasi utama setiap anak. Apalagi bila diajarkan pada anak usia dini, karena anak usia dini dikenal dengan sebutan golden age atau masa keemasan yang hanya datang satu kali maka tidak disia-siakan dengan menanamkan nilai keagamaan seperti budi pekerti yang baik, sopan santun, beribadah dengan baik dan benar, berakhlak yang baik, taqwa kepada Allah SWT dan lain sebagainya. Selain merencanakan kegiatan belajar mengajar, guru di labschool PIAUD IAIN Bengkulu juga memperhatikan beberapa hal dalam suatu proses perencanaan. Misalnya saja sebelum merencanakan sesuatu, guru melihat kondisi di sekitarnya mulai dari tempat atau gedung yang akan digunakan, peralatan yang akan digunakan sebagai penunjang proses belajar mengajar, serta yang tidak kalah pentingnya yaitu kondisi

25 Pidarta, M. Landasan Kependidikan. Jakarta: PT. Rineka Cipta, 2011). Hal.61 dari siswa yaitu perbedaan kelas sesuai dengan usia dan tingkat kemampuan anak.

\section{Pengorganisasian (Organizing)}

Proses penerimaan murid baru yang telah dijalankan oleh PAUD Al-Fath dalam pandangan penulis sudah baik, artinya untuk jenjang pendidikan prasekolah, tes masuk bukanlah suatu hal yang mutlak, karena pada tahap umur prasekolah (1 s.d 4 tahun) anak belum dapat diajak untuk melakukan kegiatankegiatan yang bersifat baku, karena proses befikir anak masih berpusat pada penguasaan simbol-simbol. Oleh karena setiap anak harus mendapat kesempatan yang sama untuk berkembang. Hal ini sesuai dengan pendapat J. Piaget ${ }^{26}$ bahwa: Perkembangan seorang anak, diperoleh dari kematangan dan kesempatan belajar dari berbagai respon lingkungan terhadap anak.

Organizing atau pengorganisasian merupakan langkah kedua setelah melakukan planning atau perencanaan, tidak hanya planning saja yang menjadi penentu suatu hasil dari kegiatan namun organizing atau pengorganisasian juga ikut menentukan hasil dalam suatu kegiatan demi tercapainya tujuan yang diinginkan. Pengorganisasian di labschool PIAUD

26 Patmonodewo, S., 2006. Pendidikan Anak Prasekolah. (Jakarta: PT. Rineka Cipta2006.). hal. 31 


\begin{tabular}{|l|l|r|}
\hline A1 Fitrah & Manajemen Pengelolaan Labschool Program \\
Journal Of Early Childhood Islamic Education & Studi PIAUD Fakultas Tarbiyah dan Tadris \\
ISSIN Bengkulu \\
ISS : 2599-2287 & Yenti Sumarni \\
\hline
\end{tabular}

IAIN Bengkulu menjalin kerjasama yang erat antara penyelenggara, kepala sekolah, guru, orang tua, masyarakat setempat, dan pemerintah setempat. Berikut adalah beberapa contoh kerjasama yang dilakukan: (1) Menjalin kerjasama antara penyelenggara, kepala sekolah, dan guru. (2) Menjalin kerjasama dengan orang tua. (3) Menjalin kerjasama dengan masyarakat setempat. (4) Menjalin kerjasama dengan pemerintahan setempat.

Namun dalam konteks manajemen keuangan labschool PIAUD IAIN Bengkulu belum dilaksanakan sebagaimana diharapkan, artinya pembiayaan penunjang pendidikan selama ini masih bertumpu pada sumber dana iuran orang tua/SPP dan bantuan insidental dari Pemerintah. Dalam pandangan penulis, yang belum dilaksanakan secara terorganisir di labschool PIAUD IAIN Bengkulu adalah pemanfaatan sarana yang ada belum dilakukan secara optimal. Hal ini dikarenakan sekolah belum memiliki buku inventarisasi sarana dan prasarana secara lengkap sehingga banyak barang/ sarana/ alat peraga yang tidak diketahui keberadaannya.

3. Pelaksanaan (Actuating)

labschool PIAUD IAIN Bengkulu memiliki pola pengelolaan tersendiri, karena letak dari labschool PIAUD IAIN
Bengkulu berada di lingkungan yang mayoritas penduduknya beragama Islam oleh sebab itu labschool PIAUD IAIN Bengkulu memiliki visi, misi dan tujuan seperti menyiapkan generasi yang berakhlaqul karimah, dalam pelaksanaanya untuk mewujudkan hal tersebut labschool PIAUD IAIN Bengkulu memiliki kegiatan unggulan seperti menghafalkan doa seharihari, menghafalkan surat-surat pendek, menghafalkan asmaul husna dengan bernyanyi, belajar cara berwudhu yang benar dengan cara bernyanyi agar mudah diingat anak, serta menghafalkan gerakan sholat dengan baik dan benar. Bahkan dari kegiatan unggulan keagamaan itulah yang mendorong orang tua memasukan anaknya untuk bersekolah di labschool PIAUD IAIN Bengkulu.

Pola pengelolaan pengajaran atau metode yang digunakan guru labschool PIAUD IAIN Bengkulu dalam memberikan materi biasanya berbentuk metode ceramah, yaitu melakukan media pembelajaran dengan cara menginformasikan secara lisan dimana anak didik sifatnya hanya mengamati, melihat, dan mendengarkan apa yang disampaikan oleh guru. Sebagai contoh, guru di labschool PIAUD IAIN Bengkulu pada hari-hari tertentu mengisi materi 


\begin{tabular}{|c|c|c|}
\hline restomive & \begin{tabular}{|l} 
Al Fitrah \\
Journal Of Early Childhood Islamic Education \\
ISSN : 2599-2287 \\
Vol.1 No.2 Januari 2018
\end{tabular} & $\begin{array}{r}\text { Manajemen Pengelolaan Labschool Program } \\
\text { Studi PIAUD Fakultas Tarbiyah dan Tadris } \\
\text { IAIN Bengkulu } \\
\text { Yenti Sumarni }\end{array}$ \\
\hline
\end{tabular}

dongeng dengan bercerita tentang binatang.

Guru menjelaskan mengenai bentuk secara fisik binatang yang diceritakan serta menjelaskan tentang karakter dari binatang tersebut dan anak hanya mendengarkan apa yang disampaikan oleh guru. Selain metode ceramah yang digunakan, guru di labschool PIAUD IAIN Bengkulu juga menggunakan metode demonstrasi yaitu memberikan materi dengan memperagakannya secara langsung di depan anak, contohnya ketika guru menjelaskan tentang cara berwudhu yang benar, pada saat itu guru memperagakannya dan membuatkan lagu untuk setiap gerakan agar anak lebih mudah menghafalkannya bila terdapat lagu di materi tersebut. Kedua metode tersebut sering digunakan guru labschool PIAUD IAIN Bengkulu dalam membantu penyampaian materi pembelajaran. Selain kedua metode tersebut yang tidak kalah seringnya digunakan dalam membantu metode ceramah dan demonstrasi adalah metode bernyanyi. Bernyanyi selalu dilakukan guru dalam pemberian materi agar siswa lebih mudah untuk menghafalkan materi yang diberikan.

\section{Pengawasan (Controling)}

Menurut hasil penelitian, fungsi pengawasan pada program pendidikan anak usia dini dilakukan setiap saat, baik dimulai dari proses penerimaan murid baru, pelaksanaan kegiatan sedang berlangsung maupun setelah berakhir kegiatan.

Pengawasan di labschool PIAUD IAIN Bengkulu selama ini yang dilakukan merupakan upaya dalam melakukan pembinaan dan pengawasan dengan melakukan diskusi terfokus berkenaan dengan ketersediaan personil guru pendidikan anak usia dini sesuai dengan kebutuhan (berdasarkan jumlah siswa) serta upaya-upaya untuk memenuhi tugas dan kewajiban sebagai guru pendidikan anak usia dini.

Labschool PIAUD IAIN Bengkulu lebih menekankan evaluasi pada saat proses pengawasan, hal itu dilakukan karena setelah berjalanya suatu kegiatan pasti akan terjadi berbagai yang yang tidak di inginkan di luar perencanaan sebelumnya. Oleh karena itu setiap hari dibutuhkan evaluasi untuk melihat kendala apa yang dirasakan serta berusaha untuk memperbaiki kegiatan yang ada dan berani mempertanggung jawabkan atas kegiatan yang sudah terlaksana.

Controling (pengawasan) ini merupakan fungsi dari pengelolaan yang terakhir. Controling merupakan salah satu kunci yang menjadi keberhasilan dari 


\section{Al Fitrah Journal Of Early Childhood Islamic Education ISSN : 2599-2287 Vol.1 No.2 Januari 2018}

serangkaian kegiatan. Di labschool PIAUD IAIN Bengkulu controling atau pengawasan selalu dilakukan setiap hari oleh kepala sekolah dan penyelenggara memantau keadaan labschool PIAUD IAIN Bengkulu sedikitnya seminggu sekali. Selain pengawasan yang dilakukan antara penyelenggara dengan kepala sekolah dan kepala sekolah dengan guru, masyarakat juga terlibat dalam pengawasan.

Dalam kegiatan pendidikan anak usia dini pada labschool PIAUD IAIN Bengkulu, ada dua pengawasan dalam mengawasi pelaksanaan kegiatan pendidikan ini, yaitu: pengawasan atasan langsung dan pengawasan fungsional. Pengawasan atasan langsung dilakukan oleh Kepala Sekolah, sedangkan pengawasan fungsional dilakukan oleh Ketua Prodi PIUAD Fakultas Tarbiyah dan Tadris IAIN Bengkulu. Kepala sekolah adalah pengawasan yang merupakan atasan langsung atau sering disebut pengawasan melekat. Hal ini dikarenakan salah satu kegiatan pengawasan yang merupakan tugas dan tanggung jawab setiap pimpinan sebagai penyelenggara manajemen.

Dalam hal pengawasan, selain kedua pengawasan tersebut, ada beberapa pihak yang turut dalam hal pengawasan masyarakat dan orang tua wali siswa.
Manajemen Pengelolaan Labschool Program Studi PIAUD Fakultas Tarbiyah dan Tadris IAIN Bengkulu Yenti Sumarni

Sejalan dengan hal tersebut, Pidarta ${ }^{27}$ menjelaskan adanya hubungan saling memberi dan menerima antara lembaga pendidikan dan masyarakat sekitarnya. Lembaga pendidikan merealisasi cita-cita masyarakat tentang pengembangan anakanak mereka. Lembaga pendidikan memberikan sesuata yang sangat berharga kepada masyarakat. Selanjutnya, orang tua yang memberikan dukungan kuat kepada anakanaknya akan membuat anak-anak senang dan bersemangat ke sekolah. Ini berdampak positif pula pada guru dalam memberikan pelajaran pada anak. Namun pada kenyataannya tidak semua orang tua punya perhatian terhadap pendidikan dan perkembangan anaknya.

\section{Daftar Pustaka}

Bambang Hartoyo. 2004. Konsep Dasar Pendidikan Anak Usia Dini. Materi Tutor dan Pengelola Pendidikan Anak Usia Dini, di BPPLSP Regional III Jawa Tengah.

David, R. F. 2004. Konsep Manajemen Strategis. PT Indeks (VII).

Depdiknas. 2007. Menuju Pendidikan yang Bermutu dan Merata. Jakarta: Balai Pustaka.

Depdiknas. 2002. Kurikulum Hasil Belajar Pendidikan Anak Usia Dini. Jakarta: Depdiknas.

27 Pidarta, M. Landasan
Kependidikan... hal. 184 


\begin{tabular}{|c|c|c|}
\hline 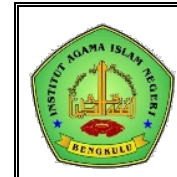 & $\begin{array}{l}\text { A1 Fitrah } \\
\text { Journal Of Early Childhood Islamic Education } \\
\text { ISSN : 2599-2287 } \\
\text { Vol.1 No.2 Januari } 2018\end{array}$ & $\begin{array}{r}\text { Manajemen Pengelolaan Labschool Program } \\
\text { Studi PIAUD Fakultas Tarbiyah dan Tadris } \\
\text { IAIN Bengkulu } \\
\text { Yenti Sumarni }\end{array}$ \\
\hline
\end{tabular}

Didin Kurniadin \& Imam Machali. 2012.

Manajemen Pendidikan Konsep \&

Prinsip Pengelolaan Pendidikan.

Yogyakarta: Ar-Ruzz Media.

Dyah Fifin Fatimah dan Nur Rohma. 2016.

Pola Pengelolaan Pendidikan Anak

Usia Dini di Paud Ceria Gondangsari

Jawa Tengah. Jurnal Manageria:

Jurnal Manajemen Pendidikan Islam

Volume 1, Nomor 2

Fari Ulfah. 2015. Manajemen PAUD

Pengembangan Jejaring Kemitraan

Belajar, Yogyakarta: Pustaka Pelajar.

Hasibuan, S. P. M. 1995. Manajemen

Sumber Daya Manusia (II). Jakart:

PT Toko Gunung Agung

Kadarman, A. M. et. a. Pengantar Ilmu

Manajemen. Jakart: gramedia. 1996

Malayu. 2006. Manajemen. Jakarta: Bumi

Aksara

Mansur. 2009. Pendidikan Anak Usia Dini

Dalam Islam. Yogyakarta: Pustaka Pelajar.

Mondy, R.W.and Premeaux, S. 1995.

Management: Concepts, Practices and Skills. New Jersey: Prentice Hall Inc Englewood Cliffs.
Mukhtar Latif, dkk, 2014. Orientasi Baru Pendidikan Anak Usia Dini Teori dan Aplikasi, (Jakarta: Kencana Prenademedia

Oxford. 2005. Learner's Pocket Dictionary. Newyork, Oxford University Press..

Padu, 2004. Buletin PADU. Jurnal Ilmiah Anak Usia Dini, Jakarta: Departemen Pendidikan Nasional

Patmonodewo, S., 2006. Pendidikan Anak

Prasekolah. Jakarta: PT. Rineka Cipta.

Pidarta, M. 2011. Landasan Kependidikan. Jakarta: PT. Rineka Cipta

Republik Indonesia, Undang-undang RI No. 14 Tahun 2005 tentang Guru dan Dosen, Bab IV, Pasal 8 \& 9

Republik Indonesia, Undang-undang Dasar 1945, pembukaan.

Republik Indonesia Undang-undang RI No.16 Tahun 2007.

Rusdiana. 2015. Pengelolaan Pendidikan. Bandung: Pustaka Setia.

Tn. 2010. Himpunan Perundang-Undangan Republik Indonesia tentang SISDIKNAS dan Penyelenggaraan Pendidikan. Bandung: Citra Umbara. 